\title{
PENGATURAN BENTUK USAHA PENANAMAN MODAL ASING DI INDONESIA
}

\author{
Hamam Febrian Cahaya, I Nyoman Putu Budiartha, Putu Ayu Sriasih Wesna \\ Fakultas Hukum Universitas Warmadewa, Denpasar-Bali, Indonesia \\ haman@gmail.com, budiarthaputu59@gmail.com, ayuwesna@gmail.com
}

\begin{abstract}
Abstrak
Pengaturan pendirian badan usaha penanaman modal asing di bidang perdagangan Jasa ekspor telah diundangkan melalui Undang-Undang Nomor 25 Tahun 2007 tentang Penanaman Modal, sebagaimana dimuat pada Pasal 5 ayat 2 ditentukan bahwa perusahaan yang diartikan menurut pasal yang berlaku untuk semuanya atau potongan paling besar di Indonesia sebagai satu kesatuan perusahaan itu sendiri diharuskan sudah terbentuk menjadi badan hukum yang menurut hukum positif Indonesia dan yang bertempat di Indonesia. Penelitian ini bertujuan untuk untuk mengetahui pengaturan pendirian badan usaha penanaman modal asing di bidang jasa perdagangan ekspor, dan untuk mengetahui kebijaksanaan dan instrumen hukum yang dilakukan oleh Badan Koordinasi Penanaman Modal Daerah dalam meningkatkan iklim penanaman modal asing di bidang perdagangan ekspor. Metode penelitian yang dipergunakan adalah metode penelitian hukum normatif. Sumber bahan hukum yang digunakan terbagi atas bahan hukum primer, sekunder dan tersier. Hasil penelitian menunjukkan bahwa Pengaturan pendirian badan usaha PMA di bidang perdagangan Jasa ekspor diatur dalam UU PM dalam Bab IV Bentuk Hukum, Kedudukan dan Daerah Berusaha, sebagaimana dimuat pada Pasal 5 ayat 2 disebutkan bahwa Perusahaan yang dimaksud dalam penanaman modal asing diwajibkan berbentuk PT atas dasar hukum positif Indonesia dan berada di wilayah NKRI, terkecuali telah ditentukan lain oleh UU Badan hukum yang ada di Indonesia adalah perseroan terbatas yang telah memiliki fundamen tersendiri sebagaimana disebutkan dalam Pasal 1 UU PT adalah badan hukum yang berdiri atas suatu perjanjian yang menjalankan giat bisnis dengan dasar aset yang telah dibagi menjadi modal yang disuntik oleh investor dan telah memenuhi segala persyaratan yang telah diatur dalam UU ini serta dalam peraturan pelaksanaanya.
\end{abstract}

Kata kunci: Bentuk Usaha; Pengaturan; Penanaman Modal Asing

\begin{abstract}
The regulation on the establishment of a foreign investment business entity in the field of export services trade has been promulgated through Law Number 25 of 2007 concerning Investment, as contained in Article 5 paragraph 2 it is determined that the company defined according to the article which applies to everything or the largest discount in Indonesia as a single entity, the company itself is required to have been formed into a legal entity according to Indonesian positive law and domiciled in Indonesia. This study aims to determine the arrangements for the establishment of foreign investment business entities in the export trade service sector, and to determine the policies and legal instruments implemented by the Regional Investment Coordinating Board in improving the foreign investment climate in the export trade sector. The research method used is the normative legal research method. Sources of legal materials used are divided into primary, secondary and tertiary legal materials. The results showed that the regulation on the establishment of a PMA business entity in the field of export services is regulated in the PM Law in Chapter IV Legal Forms, Position and Business Area, as contained in Article 5 paragraph 2, it is stated that the company referred to in foreign investment is obliged to be in the form of a PT on the basis of positive law in Indonesia and is in the territory of the Republic of Indonesia, unless otherwise stipulated by the Law. Legal entities in Indonesia are limited liability companies that have their own fundamentals as stated in Article 1 of the PT Law is a legal entity that stands on an agreement that carries out active business on the basis of assets that have been divided into capital injected by investors and have met all the requirements stipulated in this law and in its implementing regulations.
\end{abstract}

Keywords: Business Form; Settings; Foreign investment

\section{PENDAHULUAN}

Setelah diberlakukannya Undang-Undang Nomor 22 Tahun 1999 sebagaimana telah diganti dengan Undang-Undang Nomor 32 Tahun 2004 tentang Pemerintah Daerah (selanjutnya disebut UU Pemda), kewenangan investasi (penanaman modal) telah menjadi wewenang dari pemerintah daerah tingkat II Secara menyeluruh wewenang pemerintah daerah tingkat II yaitu wewenang pekerjaan umum, 
kesehatan, pendidikan dan kebudayaan, pertanian, perhubungan, industri dan perdagangan, penanaman modal, lingkungan hidup, pertanahan, koperasi dan tenaga kerja (Martono, 2005).

Arah kebijaksanaan penanaman modal yang dimaksud untuk meningkatkan ekspor khususnya di bidang jasa perdagangan hanya dapat dilakukan dengan jalan peningkatan dan penyempurnaan baik modal, keahlian dan teknologi (Abidin, 2017; Khairul Rahman, 2015). Keberadaan jenis usaha jasa perdagangan ekspor, hendaknya didukung oleh fasilitas yang memadai Kegiatan usaha di bidang ekspor impor, fasilitas organizer pameran promosi tingkat nasional dan internasional Penanaman modal asing yang tinggi untuk sub sektor jasa perdagangan ekspor antara lain usaha furniture, garmen dan kerajinan tangan Dalam menjaga agar kegiatan dunia usaha dapat berjalan dan berkembang dengan baik untuk itu BKPMD/BPM berupaya untuk melindungi serta membina usaha dengan memberikan atau arah yang jelas dan pasti bagi dunia usaha.

Berdasarkan uraian permasalahan yang telah dikemukakan diatas, maka penelitian dirumuskan untuk mengetahui pengaturan pendirian badan usaha penanaman modal asing di bidang jasa perdagangan ekspor, dan untuk mengetahui kebijaksanaan dan instrumen hukum yang dilakukan oleh Badan Koordinasi Penanaman Modal Daerah dalam meningkatkan iklim penanaman modal asing di bidang perdagangan ekspor.

\section{METODE PENELITIAN}

Metode penelitian yang dipergunakan adalah metode penelitian hukum normatif. Sumber bahan hukum yang digunakan terbagi atas bahan hukum primer adalah bahan hukum yang utama yang menjadi dasar kajian dari penelitian ini. Bahan hukum sekunder adalah adalah bahan hukum yang digunakan untuk menunjang atau membantu dalam memberikan pemahaman-pemahaman dan gambaran-gambaran serta teori-teori hukum yang digunakan untuk mengulas dan memecahkan persoalan-persoalan yang akan diteliti di dalam penelitian ini. Bahan Hukum Tersier adalah bahan hukum yang memberikan petunjuk maupun penjelasan terhadap bahan hukum primer dan sekunder (Soekanto \& Mamudji, 2006). Untuk memperoleh bahan-bahan hukum primer, sekunder dan tersier digunakan teknik inventarisasi atau penelusuran bahan hukum yang bersangkutan lalu di klasifikasi atau dikelompokan dan didokumentasikan, dicatat, dikutip, diringkas, diulas sesuai kebutuhan dengan pendekatan kualitatif. Setelah bahan hukum primer dan bahan hukum sekunder terkumpul, maka bahan hukum tersebut akan diolah dan dianalisis dengan menggunakan metode pengolahan bahan hukum secara sistematis.

\section{HASIL DAN PEMBAHASAN}

\section{Pengaturan Pendirian Badan Usaha Penanaman Modal Asing di Bidang Jasa Perdagangan Ekspor}

Pasang surut suatu kegiatan investasi selain dipengaruhi oleh faktor internal seperti potensi alam, demografi dan berbagai deregulasi, juga sangat dipengaruhi faktor eksternal. Faktor eksternal menyebabkan menurunnya total modal direlokasikan dari negara-negara maju ke negara berkembang. Perkembangan investasi di Indonesia didominasi negara-negara asia timur. Berkurangnya arus investasi disebabkan oleh beberapa negara maju sedang mengalokasikan sebagian dananya bersifat sosial di samping Indonesia menghadapi tawaran dari negara asing Upaya menanggulangi penurunan ekonomi dan juga pembangunan yang berkelanjutan daripada daya perdagangan mesti berlandaskan akan potensi dan kemampuan masyarakat Indonesia. Dengan adanya asas ini tidak boleh timbulnya ketidakberanian akan menggunakan potensi yang ada baik itu aset, teknologi dan kemampuan yang ada dari pihak luar negeri, selama pertolongan itu diberikan tertuju kepada kepentingan ekonomi rakyat dan tidak menimbulkan suatu ketergantungan terhadap pihak luar negeri.

Dalam Undang-Undang Republik Indonesia Nomor 25 Tahun 2007 tentang Penanaman Modal (selanjutnya disebut UU PM) dalam Bab IV Bentuk Hukum, Kedudukan dan Daerah Berusaha pada pasal 5 ayat 2 ditentukan bahwa perusahaan yang dimaksud dalam penanaman modal asing diwajibkan berbentuk PT atas dasar hukum positif Indonesia dan berada di wilayah NKRI, terkecuali telah ditentukan lain oleh badan hukum yang ada di Indonesia adalah perseroan terbatas yang telah memiliki fundamen tersendiri sebagaimana disebutkan dalam Pasal 1 Undang- Undang Nomor 40 Tahun 2007 tentang Perseroan terbatas (selanjutnya disebut UU PT) ialah badan hukum yang berdiri atas suatu perjajian yang menjalankan aktivitas bisnis dengan dasar aset yang telah dibagi menjadi 
sokongan dana dari para investor dan telah memenuhi segala persyaratan yang telah diatur dalam UU ini serta dalam peraturan pelaksanaanya (Budi Jaya, 2004).

Dari pengertian mengenai badan hukum yang dimaksud bahwa jelaslah untuk usaha atau investor yang menanamkan modalnya di Indonesia mendirikan suatu badan hukum yang berdasar atas hukum Indonesia, yakni Perseroan Terbatas (PT) yang telah memiliki perangkat sendiri yakni UU PT (Perseroan Terbatas) dahulunya merupakan bagian dari KUHD (Wetboek van Koophandel dalam bahasa Belanda, yang disingkat WvK), kemudian lambat laun mengalami penyesuaian dengan keadaan kemajuan atau perkembangan pertumbuhan ekonomi. Pendirian PT disebutkan dalam UU PT antara lain:

1. Akta pendirian diaktakan di depan notaris yang telah termuat mengenai AD PT

2. Pengesahan oleh MenKumHAM sesuai dengan Pasal 7 ayat 6 UU PT

3. Pendaftaran perseroan merupakan wajib daftar perusahaan beserta surat pengesahan MenKumHAM dalam waktu 30 hari sesuai dengan Pasal 21 UU PT, pendaftaran perusahaan sebagaimana dimaksud dalam UU wajib daftar perusahaan

4. Pengumuman dalam tambahan berita negara sesuai dengan pasal 22 UU PT, dimana permohonan dilakukan oleh Direksi dengan waktu 30 hari terhitung sejak pendaftaran (Rajagukguk, 2004).

Menghadapi problema seperti itu pemerintah hendaknya selalu mendukung segala kepentingan rakyatnya baik itu konsumen atau produsen dari kerjasamanya dengan pihak asing. Untuk menciptakan iklim bisnis yang sehat, pemerintah hendaknya membuat cara agar kepemilikan akan unit usaha yang di bidang penanaman modal asing sangat besar dengan tetap menjunjung dari landasan filsafat hukum yaitu suatu proses kebijaksanaan dalam bidang perekonomian dengan selama tidak bertentangannya dari asas demokrasi ekonomi dan jiwa UU negara Republik Indonesia 1945 karenanya perlu diantisipasi dengan dasar hukum yang jelas. UU PM merupakan undang-undang organik yang mengatur tentang Penanaman Modal di Indonesia. Untuk melengkapi modal dan teknologi guna pelaksanaan pembangunan di tanah air kita yakni tanah air Indonesia, maka pemerintah sebagai bagian dari hirarki pemerintahan dengan penuh tanggung jawab yang didasari atas kewaspadaan dan pertimbangan untuk menggunakan kekuatan- kekuatan aset, teknologi dan kemampuan yang ada dari pihak luar negeri dengan penggunaan yang sebenarnya untuk kepentingan rakyat dan tanpa mengakibatkan ketergantungan kepada pihak luar negeri. Indonesia pada saat ini dalam tahap Pembangunan Ekonomi (Suli, 2003). Pembangunan ekonomi yang utama memiliki pengertian akan kekuatan mengolah kepotensialan ekonomi yang akan menjadi suatu kekuatan riil dengan penanaman modal, penggunaan teknologi (Indonesia, 2016).

\section{Kebijakan dan Instrumen Hukum yang Dilakukan oleh Badan Koordinasi Penanaman Modal Daerah dalam Meningkatkan Penanaman Modal Asing di Bidang Jasa Perdagangan Ekspor}

Kebijaksanaan di bidang Penanaman Modal Asing melalui keputusan ketua Badan Penanaman Modal sebenarnya merupakan revisi atas undang-undang tentang Penanaman Modal Asing, sehubungan dengan hal tersebut seharusnya agar tercipta suatu kepastian hukum, maka diubah bentuknya adalah undang-undang, perubahannya harus pula dilakukan dengan suatu undang-undang, jadi tidak cukup hanya dengan semacam surat keputusan. Hal ini perlu mendapat suatu perhatian yang layak, sehingga terciptanya suatu kepastian hukum sehingga para investor asing dapat merasa aman dan terlindungi karena dari aspek hukum ada jaminan yang kuat bagi bisnis mereka. Penanaman modal yang berkualitas didasarkan atas kondisi daerah, kemampuan daya mendukung lahan untuk investasi, pelestarian lingkungan dalam rangka pembangunan yang berkelanjutan dan merata di seluruh wilayah atau daerah Peraturan sebagai fundamen dalam mengatur penanaman modal sebelum diimplementasikan hendaknya dikaji secara matang, sehingga peraturan perundang-undangan tersebut berlaku berkepanjangan.

Adapun kebijakan yang dikeluarkan oleh pemerintah pusat dalam rangka memikat daya tarik para penanam modal asing asing untuk menanamkan modalnya di Indonesia, dalam UU PM yang mengatur mengenai tax privileges, hak transfer dalam valuta asing dari aset dasar nilai tukar yang berlaku, manajemen tenaga kerja, jaminan pemerintah untuk tidak akan melakukan nasionalisasi kecuali kepentingan negara menghendaki, jaminan untuk memberikan kompensasi jika benar-benar telah terjadi nasionalisasi dan jaminan pemakaian prosedur penyelesaian sengketa secara damai. Di samping bentuk insentif diberikan oleh pemerintah tersebut di atas juga pemerintah memberikan kemudahan dalam bentuk penggunaan tanah kepada investor asing di Indonesia umumnya Dalam 
PMA diberikan penggunaan tanah sesuai dengan hukum yang berlaku bagi pemakai hak atas tanah di Indonesia Sesuai dengan UU PM (Soimin, 2001).

Guna menjamin kepastian hukum para investor maka peraturan mengenai penggunaan tanah sebagaimana telah diatur dalam UUPA diperbaharui untuk menciptakan suasana baru dalam rangka investasi yang layak dan aman yakni dengan dikeluarkannya PP No 20 Tahun 1994 bahwa HGB dan HGU dapat diperoleh oleh perusahaan penanaman modal asing sepenuhnya seratus persen. Untuk menghindarkan keragu-raguan pihak luar untuk melakukan investasi dalam rangka memajukan perekonomian maka pemerintah dalam menghadapi situasi tersebut mengundangkan UU PM Dengan diperlukannya peraturan yang efektif dalam memenuhi kebutuhan akan modal untuk menjalankan pembangunan nasional guna menghindari akan tidak kepercayaan para PMA. Usaha-usaha yang diberikan oleh pihak internasional kepada pihak Indonesia dalam hal investasi yang diawali dengan terbentuknya IGGI (Inter Governmental Group to Indonesia) yang beranggotakan Australia, Belgia, Perancis, Italia, Belanda, Inggris, Amerika Serikat, Selandia Baru, Kanada dan Jepang Tujuan diadakan kerjasama seperti ini adalah merupakan suatu usaha untuk peningkatan dalam perekonomian Indonesia khususnya taraf hidup rakyat kecil, dengan batas kewajaran politik bebas aktif yang murni tanpa merugikan kepentingan nasional. Dalam hal penanaman modal asing di bidang jasa perdagangan, pihak asing pada dasarnya lebih menyukai melakukan investasi dalam bentuk joint venture, oleh karena mitra lokal mempunyai ilmu yang luas akan kebiasaan, kebijaksanaan ekonomi dan keadaan ekonomi lokal Selain daripada itu kerjasama yang terbentuk dirasakan lebih mudah dalam perihal menembus pasar domestik, mendapatkan kemudahan dari badan yang memiliki kewenangan, sehingga hal itu menyebabkan kerjasama yang terjalin lebih baik.

\section{SIMPULAN DAN SARAN}

\section{Simpulan}

a. Pengaturan pendirian badan usaha PMA di bidang perdagangan Jasa ekspor diatur dalam UU PM dalam Bab IV Bentuk Hukum, Kedudukan dan Daerah Berusaha, sebagaimana dimuat pada Pasal 5 ayat 2 disebutkan bahwa Perusahaan yang dimaksud dalam penanaman modal asing diwajibkan berbentuk PT atas dasar hukum positif Indonesia dan berada di wilayah NKRI, terkecuali telah ditentukan lain oleh UU Badan hukum yang ada di Indonesia adalah perseroan terbatas yang telah memiliki fundamen tersendiri sebagaimana disebutkan dalam Pasal 1 UU PT adalah badan hukum yang berdiri atas suatu perjanjian yang menjalankan giat bisnis dengan dasar aset yang telah dibagi menjadi modal yang disuntik oleh investor dan telah memenuhi segala persyaratan yang telah diatur dalam UU ini serta dalam peraturan pelaksanaanya.

b. Kebijaksanaan atau instrumen hukum yang dilaksanakan oleh Badan Koordinasi Penanaman Modal Daerah Provinsi Bali dalam meningkatkan iklim penanaman modal asing di bidang perdagangan jasa ekspor, kebijakan yang diambil guna menarik para investor dalam melakukan suatu investasinya di Provinsi Bali umumnya. Badan Koordinasi Penanaman Modal Daerah Provinsi Bali masih berpedoman pada Surat Deputi Bidang Pengembangan Pengusahaan Nasional, BPM Nomor S-35/DU-5BKPM/2001 tentang bidang promosi dan kerjasama internasional penanaman modal meliputi pengelolaan pengembangan akan penanaman modal daerah baik itu di dalam negeri maupun di luar negeri. Penyusunan pengembangan bahan penanaman modal daerah dilakukan dengan menggunakan media cetak, melakukan suatu kerja sama dengan pemerintah provinsi maupun pemerintah pusat untuk terselenggaranya pengembangan akan modal daerah, pelaksanaan kemitraan, kerja sama dengan pihak ketiga sebagai langkah promosi di luar negeri, pengiriman misi ke luar negeri, penerimaan misi penanaman aset dari daerah lain dan luar negeri, kerjasama dengan luar negeri sepanjang tidak bertentangan dengan pemerintah pusat, penyiapan perjanjian guna kerjasama sub regional, sosialisasi kepada aparatur dan dunia usaha dalam bidang penanaman modal. Kewenangan lain jika tidak berlawanan dengan aturan yang dibuat oleh pemerintah pusat maupun daerah Bagian sarana pengurusan izin PM, diantaranya diberikannya persetujuan atas penyeluruhan proyek ataupun perluasan Penanaman Modal Dalam Negeri (PMDN) yang menjadi otoritas Pemerintah daerah atau Pemerintah pusat, diberikannya persetujuan akan perubahan atas proyek PMDN, pemberian perizinan, pemberian izin kerja bagi WNA yang melakukan tugas kerja di suatu daerah kota ataupun kabupaten, pemberian insentif sebatas kewenangan, penyelenggaraan kewenangan lain, di samping langkah tersebut juga langkah yang diambil oleh Badan Koordinasi Penanaman 
Modal Daerah Provinsi Bali dalam meningkatkan investasi adalah menciptakan persaingan investasi yang sehat, khusus dalam perdagangan dilakukan dengan pemotongan tarif dan mengurangi tata niaga, melakukan pembinaan

\section{Saran}

Berdasarkan simpulan tersebut diatas, dapat dikemukakan saran kepada para pihak terkait, sebagai berikut:

a. Kepada Pemerintah, agar pemerintah dalam mengembangkan iklim investasi lebih besar kepada pihak luar membuat suatu perangkat aturan yang jelas terhadap investasi, sehingga orang dan atau badan hukum melakukan suatu investasi pada setiap daerah yang memiliki potensi dan tingkat perkembangan perekonomian di samping juga fundamen yang mengatur jelas dan tidak berubahubah.

b. Kepada Masyarakat, dengan meningkatkan ekspor baik kuantitas, kualitas maupun diversifikasi komoditi, menambah dan memperluas lapangan kerja yang diharapkan akan dapat dan mampu menampung angkatan kerja yang cukup banyak jumlahnya, memberikan kesempatan memiliki setidak-tidaknya kesempatan ikut serta memiliki dan mengelola perusahaan, pengembangan teknologi termasuk dalam hal ini usaha alihketerampilan, memeratakan pendapatan (income) masyarakat dalam rangka meningkatkan pertumbuhan kesejahteraan masyarakat

\section{DAFTAR PUSTAKA}

Abidin, R. F. (2017). Harmonisasi Peraturan Penanaman Modal Asing dalam Bidang Pertambangan Mineral dan Batubara Berdasarkan Prinsip Keadilan (Studi Kontrak Karya antara Pemerintah Republik Indonesia dengan PT. Freeport Indonesia). Az Zarqa', 9(2), 315-364.

Budi Jaya, I. N. (2004). Pelatihan Hukum Bisnis. Denpasar.

Indonesia, D. P. R. (2016). Himpunan Ketetapan- ketetapan MPRS Tahun 1966. Jakarta: Depen.

Khairul Rahman. (2015). Strategi Peningkatan Investasi Pedesaan dalam Meningkatkan Perekonomian Desa di Provinsi Riau. Wedana, 1(1), 162-174.

Martono. (2005). Bank dan Lembaga Keuangan Lainnya. Yogyakarta: Liberty.

Rajagukguk, E. (2004). Indonesianisasi Saham. Jakarta: Rineka Cipta.

Soekanto, S., \& Mamudji, S. (2006). Penelitian Hukum Normatif Tinjauan Singkat. Jakarta: Rajawali Pers.

Soimin, S. (2001). Status Hak dan Pembebasan Tanah. Jakarta: Sinar Grafika.

Suli, S. (2003). Politik Luar Negeri Bebas dan Aktif Republik Indonesia. Jakarta: Research. 